\title{
Immunogenetics of human minor histocompatibility antigens: their polymorphism and immunodominance
}

\author{
C. A. C. M. van Els ${ }^{1}$, J. D’Amaro, J. Pool, E. Blokland, A. Bakker, P. J. van Elsen , J. J. van Rood, and \\ E. Goulmy
}

Department of Immunohaematology and Blood Bank, University Hospital Leiden, P. O. Box 9600, 2300 RC Leiden, and

${ }^{1}$ Department for Immunobiology, RIVM, P. O. Box 1, 3720 BA Bilthoven, the Netherlands

Received June 24, 1991

\begin{abstract}
Minor Histocompatibility $(\mathrm{mH})$ antigens are polymorphic endogenously synthesized products that can be recognized by alloreactive $T$ cells in the context of major histocompatibility complex molecules. In transplant situations where tissue donor and recipient are matched for HLA, $\mathrm{mH}$ antigens may trigger strong cellular immune responses. To gain insight into the polymorphism of $\mathrm{mH}$ antigens we studied their frequencies in the healthy population. Five HLA class I restricted $\mathrm{mH}$ antigens recognized by distinct cytotoxic T-cell (CTL) clones were used in the population genetic analysis consisting of a panel $(\mathrm{N}=100)$ of HLA typed target cells. Three $\mathrm{mH}$ antigens showed phenotype frequencies of $69 \%$ or higher, this contrasted the frequencies of two other $\mathrm{mH}$ antigens with 16 and $7 \%$ respectively. To gain insight into the "functional" polymorphism of the T-cell response to $\mathrm{mH}$ antigens, we analyzed the specificity of CTL clones within individuals. Three out of five individuals investigated shared a CTL response to one single HLA-A2 restricted $\mathrm{mH}$ antigen. These results indicate limited allelic polymorphism for some $\mathrm{mH}$ antigens in the healthy population and are suggestive of the existence of immunodominant human $\mathrm{mH}$ antigens.
\end{abstract}

\section{Introduction}

In the mouse almost 50 minor Histocompatibility $(\mathrm{mH})$ antigen genes have been mapped and congenic strains have been used to obtain information on polymorphism and immunogenecity (for a review see Loveland and Simpson 1986; Wettstein 1989). Recently, new aspects of the biochemical nature of two classical murine $\mathrm{mH}$ an-

Address correspondence and offprint requests to: E. Goulmy. tigens have become available. Using specific CTL lines as in vitro tools, Rötzschke and colleagues (1990a) found that, as is true for other $T$ cell recognized antigens such as viral and non-viral proteins (Demotz et al. 1989), the $\mathrm{mH}$ antigens $\mathrm{H}-\mathrm{Y}$ and $\mathrm{H}-4$ are naturally processed proteins, probably of peptidic nature (Rötzschke et al. 1990b; Falk et al. 1990).

Unlike the situation in experimental animal models, $\mathrm{mH}$ antigens in outbred species, such as humans, are difficult to identify and quantitate. To date mainly bone marrow transplant (BMT)-related information is available. We and other groups reported that both MHC class I restricted cytotoxic T cells (CTL) (Goulmy 1988; Van Els et al. 1990; Irle et al. 1985; Pierson and Elkins 1987) and MHC class II restricted proliferating T cells (Van Els et al. 1990; Reinsmoen et al. 1984) reactive to $\mathrm{mH}$ antigens are commonly found after HLA-identical BMT. Some of these $\mathrm{mH}$ antigens appear to be widely expressed on various tissues throughout the body, whereas others show limited tissue distribution (M. de Bueger, A. Bakker, F. van der Woude, J. J. van Rood, E. Goulmy, submitted). For BMT, it is especially relevant to know whether the number of $\mathrm{mH}$ antigens that can trigger a CTL response in a given transplant situation is very large, or whether the response may be restricted to a few $\mathrm{mH}$ antigenic determinants. To address this question we studied the antihost $\mathrm{mH}$ antigen-specific CTL response of five different bone marrow recipients at the clonal level. Here we show that the $\mathrm{mH}$ antigens studied not only differ in their immunogenecity but also in their population frequencies.

\section{Materials and methods}

Blood samples. Heparinized blood samples were collected from five patients before and after HLA identical BMT, from their sibling marrow donors, and from HLA-typed unrelated individuals. Peripheral Blood 
Table 1. Minor $\mathrm{H}$ antigen specific CTL cloning.

\begin{tabular}{|c|c|c|c|c|c|}
\hline $\begin{array}{l}\text { Patient } \\
\text { designation }\end{array}$ & $\begin{array}{l}\text { CTL line } \\
\text { designation }\end{array}$ & $\begin{array}{l}\text { N. clones } \\
\text { analyzed }\end{array}$ & $\begin{array}{l}\mathrm{mH} \text { ag } \\
\text { specificity }\end{array}$ & $\begin{array}{l}\mathrm{mH} \text { ag clone } \\
\text { designation }\end{array}$ & $\begin{array}{l}\% \text { Population } \\
\text { frequency }\end{array}$ \\
\hline I & HA-1 & $\begin{array}{l}\mathbf{N}=7 \\
N=9\end{array}$ & $\begin{array}{l}\text { HA-1 } \\
\text { HA-? }\end{array}$ & B1, B3 & $69 \%$ \\
\hline II & HA-2 & $\begin{array}{l}\mathrm{N}=17 \\
\mathrm{~N}=20\end{array}$ & $\begin{array}{l}\text { HA-2 } \\
\text { HA-? }\end{array}$ & $\mathrm{A} 1, \mathrm{~A} 2$ & $95 \%$ \\
\hline III & $\mathrm{HA}-3$ & $\begin{array}{l}\mathrm{N}=27 \\
\mathrm{~N}=20\end{array}$ & $\begin{array}{l}\text { HA-3 } \\
\text { HA-? }\end{array}$ & $\mathrm{C} 1, \mathrm{C} 2, \mathrm{C} 3$ & $88 \%$ \\
\hline IV & $\mathrm{HA}-4$ & $\begin{array}{l}\mathrm{N}=8 \\
\mathbf{N}=\mathbf{1 0} \\
\mathrm{N}=11\end{array}$ & $\begin{array}{l}\text { HA-4 } \\
\text { HA-1 } \\
\text { HA-? }\end{array}$ & $\begin{array}{l}\text { D3 } \\
\text { D2 }\end{array}$ & $\begin{array}{l}16 \% \\
69 \%\end{array}$ \\
\hline $\mathrm{V}$ & HA -5 & $\begin{array}{l}\mathbf{N}=4 \\
\mathbf{N}=\mathbf{1 1} \\
\mathbf{N}=16\end{array}$ & $\begin{array}{l}\text { HA-5 } \\
\text { HA-1 } \\
\text { HA-? }\end{array}$ & $\begin{array}{l}\text { E3, E5 } \\
\text { E2 }\end{array}$ & $\begin{array}{r}7 \% \\
69 \%\end{array}$ \\
\hline
\end{tabular}

Leukocytes (PBL) were isolated by Ficoll-Isopaque density gradient centrifugation, washed, and resuspended in RPMI 1640-dimethylsulphoxide (final concentration 10\%) for cryopreservation in liquid nitrogen. The HLA class I typings of the patients were as follows: patient I: HLA-A2, -B27, -B62; patient II: HLA-A1, -A2, -B7, -B8; patient III HLA-A1, -A11, -B8, -Bw60; patient IV: HLA-A2, -A3, -B18, -B44, and patient V: HLA-A2, -A29, -B44, -B49.

Tissue culture medium. All T-cell cultures were performed in RPMI 1640 supplemented with antibiotics and $15 \%$ human serum.

Generation of $m H$ antigen specific CTL lines. Five cytotoxic T-cell lines (CTLs), previously designated HA-1 through -5 , were isolated from PBL obtained from five patients after in vivo sensitization by a bone marrow allograft from their HLA-genotypically identical siblings (Goulmy 1988). Briefly, $4 \times 10^{6}$ posttransplant PBL from patients were stimulated with $4 \times 10^{6} 30$ Gy irradiated patients' pretransplant PBL as host-specific $\mathrm{mH}$ antigen presenting cells. At day $6, \mathrm{~T}$ cells were specifically restimulated and propagated as described previously (Goulmy 1988). These five CTL lines were highly cytotoxic for host but not donor cells and were used as typing reagents for $\mathrm{mH}$ antigens in population and family studies (Goulmy 1988).

Establishment of $m H$ antigen specific CTL clones. The CTL lines were suspended at 1.5 cells $/ \mathrm{ml}$ in a feeder cell mixture and plated at 0.2 $\mathrm{ml} /$ well (i. e., 0.3 cells/well) of $96-$ well round bottom microtiter plates. This feeder cell mixture contained: 1) allogeneic PBL $\left(10^{6}\right.$ cells $/ \mathrm{ml}$ from two or three randomly selected donors, irradiated with $30 \mathrm{~Gy}$ ); 2) patient's pretransplant Epstein-Barr virus transformed B-cell line (EBV-LCL; $5 \times 10^{5}$ cells $/ \mathrm{ml}$ irradiated with $50 \mathrm{~Gy}$ ); 3) $1 \mu \mathrm{g} / \mathrm{ml}$ leucoagglutinin A (Pharmacia Uppsala, Sweden), and 4) $20 \mathrm{U} / \mathrm{ml} \mathrm{rIl-2}$ (Ortho, Braintree, MA). After 9-10 days $0.1 \mathrm{ml}$ aliquots from each well were transferred into replicate wells and were tested for host-specific cytotoxicity against ${ }^{51} \mathrm{Cr}$ labeled patient's pretransplant EBV-LCL in a standard chromium release assay (Goulmy 1988).

Expansion of CTL clones. Clones with antihost cytotoxic activity were selected and split into eigth or more wells of a 96-well plate in the presence of fresh feeder mixture. After seven days of expansion, $\mathrm{mH}$ antigen-specific cytotoxic activity of the clones was determined against a panel of target cells derived from patients, donors, and unrelated individuals. This procedure yielded among others; $12 \mathrm{mH}$ antigen-specific CTL clones, i. e., clones B1 and B3 from patient I; clones A1 and A2 derived from patient II; clones $\mathrm{C} 1, \mathrm{C} 2$, and $\mathrm{C} 3$ from patient III; clones D2 and D3 from patient IV, and clones E2, E3, and E5 from patient $V$ (see also Table 1). Large scale expansion (30-60 fold) of these clones for extensive panel typing was performed as follows: $1 \times 10^{6}$ CTLs were cultured together with $10 \mathrm{ml}$ of the above mentioned feeder cell mixture in an upright $75 \mathrm{~cm}^{2}$ tissue culture flask (angle $45^{\circ}$ ) in a total volume of $80 \mathrm{ml}$ of medium for five days. Then fresh medium containing $100 \mathrm{U} \mathrm{rIl}-2 / \mathrm{ml}$ was added for $1-3$ more days.

Cell Mediated Lympholysis (CML) assay. Cell mediated lympholysis was measured in vitro by using a standard chromium release assay (Goulmy 1988). Briefly, $5 \times 10^{351} \mathrm{Cr}$ labeled target cells, either T-lymphoblasts generated by treatment of PBL with $1 \%$ phytohemagglutinin (PHA) mitogen (Difco, Detroit, MI) for 3 days and expansion on interleukin 2 (IL-2), or EBV-LCL, were incubated together with varying numbers of CTLs so that effector:target ratios of $10: 1$ and 1:1 were obtained. After $4 \mathrm{~h}$ at $37^{\circ} \mathrm{C}$ the supernatants were harvested for counting in a gamma counter (Packard Instruments, Downers Grove, IL). Percentages of specific ${ }^{51} \mathrm{Cr}$ release were calculated according to the following formula; ER-SR/MR-SR $\times 100 \%$, in which Experimental, Spontaneous and Maximal release (ER, SR, and MR) were respectively the isotope release by target cells measured in the presence of effector cells (ER), in culture medium alone (SR), and in culture medium containing the detergent zaponine (MR).

T-cell receptor (Tcr) DNA rearrangement analysis. DNA was isolated from approximately $1-2 \times 10^{7}$ cells as described by Nicklas and coworkers (1987). Ten $\mu \mathrm{g}$ of DNA was digested with Eco R1 and Hind III enzymes (Boehringer, Mannheim, FRG) according to the manufacturer's instructions. The restriction fragments were size-fractionated in a $0.8 \%$ agarose gel and blotted onto nylon membranes (Biotrace; Gelman Sciences, Ann Arbor, MI) as described (Maniatis et al. 1982; Miltenburg et al. 1990). $T c r b$ gene rearrangements were detected with the $B g l$ II $\mathrm{C} \beta 1$ fragment of HPB- $\beta 2$ (Yoshihai et al. 1984).

\section{Results}

Isolation of $12 \mathrm{mH}$ antigen reactive CTL clones. Five CTL bulk cultures specific for $\mathrm{mH}$ antigens were obtained (Goulmy 1988) following restimulation of in vivo primed PBLs from five patients after HLA identical, but $\mathrm{mH}$ an- 
tigen nonidentical, BMT. These CTL lines were cloned by limiting dilution, resulting in the isolation of twelve $\mathrm{mH}$ antigen-specific CTL clones with codes A1, A2, B1, B3, C1, C2, C3, D2, D3, E2, E3, and E5. These CTL clones lysed the bone marrow recipient's, but not the donor's, target cells in an effector:target ratio-dependent manner, and their reactivity could be blocked by the MHC class I-specific monoclonal antibody $(\mathrm{mAb})$ w6/32 (data not shown). Analysis of DNA rearrangement patterns involving the $c \beta 1$ and $c \beta 2$ regions of the $\operatorname{Tcr} \beta$ chain confirmed the monoclonal character of CTLs A1, A2, B1, $\mathrm{C} 1, \mathrm{D} 2, \mathrm{D} 3$, and E5, but not of CTLs D3 and E2 (data not shown). The CTLs B2, C2, C3, and E3 were not tested for Tcr DNA rearrangement patterns.

Identification of four clusters of $m H$ antigen specific clones restriction by $H L A-A 2$. Since the reactivities of nine of the twelve CTLs, i. e., A1, A2, B1, B3, D2, D3, $\mathrm{E} 2, \mathrm{E} 3$, and E5, were restricted to HLA-A2, comparison of their antigenic specificities in an HLA-A2 positive healthy population was carried out (Fig. 1). All the 100 target cells selected for this purpose expressed the cellularly defined HLA-A2.1 molecule, as was assessed with an anti HLA-A2.1-specific CTL clone (data not shown), except target cell 64 which expressed a so far unidentified HLA-A2 variant molecule. As is summarized in Figure 1, the nine CTLs defined four distinct clusters of $\mathrm{mH}$ antigen specificities. Each of these specificities was identified by at least one of the CTLs which were clonal according to the $\mathrm{Tcr}$ rearrangement analysis. The specificity designated HA-1 for its strong similarity with the original CTL line HA-1, was identified by CTL clones $\mathrm{B} 1, \mathrm{~B} 3, \mathrm{D} 2$, and $\mathrm{E} 2$ and had a phenotype frequency of $69 \%$. The second specificity, exhibiting the highest frequency, designated as HA-2 (95\%) for its concordance with the original CTL line HA-2, was defined by CTL clones $\mathrm{A} 1$ and $\mathrm{A} 2$ (Fig. 1). The third specificity HA-4
(16\%), derived from the original bulk culture $\mathrm{HA}-4$, was characterized by CTL clone D3, and the fourth specificity HA-5 (7\%), isolated from the original CTL line HA-5, was defined by CTL clones E3 and E5. The only target cell which was discriminative within these clusters was the HLA-A2 variant target cell 64 . The HA-2-specific CTL clone A1, but not A2, and the HA-1-specific CTL clone $\mathrm{B} 3$, but not $\mathrm{B} 1, \mathrm{D} 2$, and $\mathrm{E} 2$, reproducibly recognized this target cell. In a separate study analyzing 13 naturally occurring HLA-A2 variants, another example was found showing the same discriminatory reaction pattern (unpublished observations).

Possible allelism for $H A-1, H A-4$, and $H A-5$. Different phenotypes of HLA-A2 positive cells could be distinguished according to the expression of zero, 1, 2, or $3 \mathrm{mH}$ antigen specificities. No panel cells were found that expressed $\mathrm{mH}$ antigens HA-1, -4 , and HA-5 simultaneously. This observation led us to investigate whether these latter specificities could be alleles at a single locus using a gene counting method of maximum likelihood and a test for Hardy-Weinberg fit (Mattiuz et al. 1970; Yasuda and Kimura 1968). Because the p-value of 0,026 was less than the minimal level of significance of $5 \%$, as one expects when comparing observed and expected values, we have to reject the hypothesis of allelism. However, inspection of the intermediate values did not reveal any extreme differences between observed and expected phenotypes (Table 2). Hence, these results could not settle the question of allelism.

Indication for immunodominance. An inventory of the $\mathrm{mH}$ antigen response at the individual level was carried out. A series of clones obtained from each of the five patients was screened for its reactivity against the $\mathrm{mH}$ antigen specificities HA-1-HA-5. As mentioned above, the selection of the CTL clones was based on its specific recipient
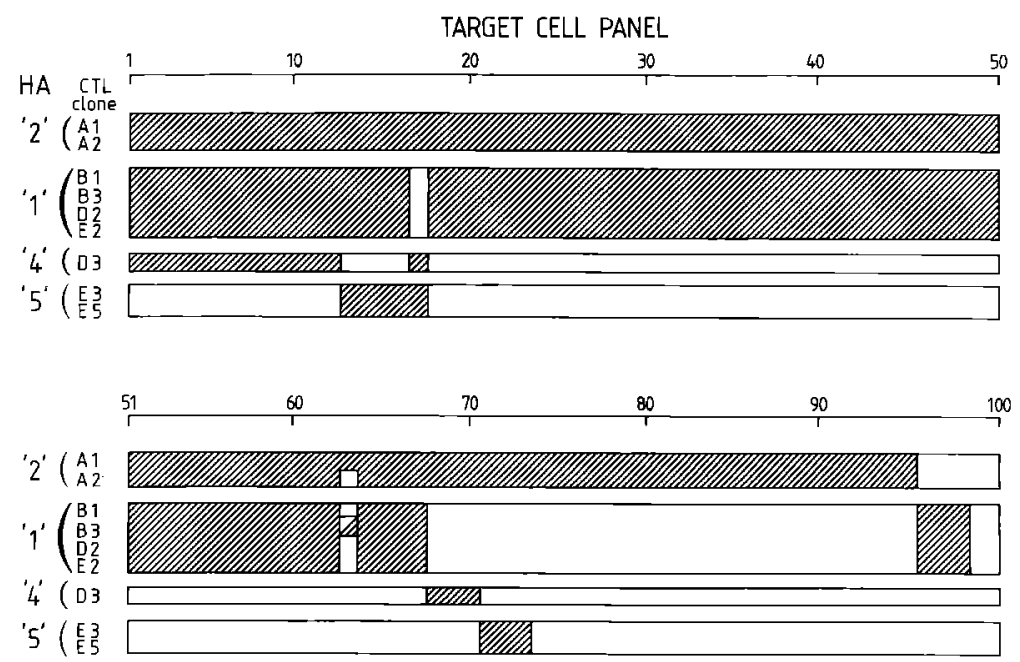

Fig. 1. Pattern of reactivity of the nine $\mathrm{mH}$ antigen specific HLA-A2 restricted CTL clones A1, A2, B1, B3, D2, D3, E2, E3, and E5 against $100 \mathrm{HLA}-\mathrm{A} 2$ + ve target cells. Clusters of concordant specificities HA-1, HA-2, HA-4, and HA-5 are indicated. All target cells are lysed by a control HLA-A2-specific alloreactive CTL clone (data not shown). 
Table 2. Fit for allelism of HA-1, HA-4, and HA-5.

\begin{tabular}{llrrll}
\hline Antigenic pair & OBS & EXP & \multicolumn{2}{c}{$\frac{(\mathrm{OBS}-\mathrm{EXP})^{2}}{\text { EXP }}$} & \\
& & & & & \\
\hline HA-1 & HA-4 & 12 & 7.400 & 2.86 & 2.86 \\
HA-1 & HA-5 & 4 & 3.159 & 0.22 & 3.08 \\
HA-1 & null & 53 & 58.440 & 0.51 & 3.59 \\
HA-4 & HA-5 & 1 & 0.595 & 0.28 & 3.87 \\
HA-4 & null & 3 & 8.004 & 3.13 & 6.99 \\
HA-5 & null & 2 & 3.247 & 0.48 & 7.47 \\
HA-5 & null & 25 & 19.155 & 1.78 & 9.26 \\
\hline
\end{tabular}

$\mathrm{X}^{2}=9.256 . \mathrm{df}=3 . \mathrm{p}=0.026004$. Gene frequencies for HA-1, HA-4, and HA-5 are $0.44322,0.08348$, and 0.03564 respectively.

Table 3. Discordancy between the $\mathrm{mH} \mathrm{HA}-2$ and HA-3 antigens.

\begin{tabular}{lll}
\hline & HA-3 & \\
\cline { 2 - 3 } & + & - \\
\hline HA-2 & & \\
+ & 30 & 5 \\
- & 2 & 1 \\
\hline
\end{tabular}

All target cells express both the HLA-A1 and -A2 antigens. Phenotype frequencies of the $\mathrm{mH}$ antigens $\mathrm{HA}-2$ and $\mathrm{HA}-3$ is $95 \%$, and $87 \%$, respectively.

cell lysis. Table 1 shows that besides the expected CTL clones specific for $\mathrm{mH}$ antigen HA-1, -4 , and -5 and CTL clones with as yet unknown $\mathrm{mH}$ antigen specificity, a number of CTL clones displaying $\mathrm{mH}$ antigen HA-1-specific reactivity were isolated not only from patient I [i. e., clones B1 and B3 (Fig. 1)] but also from patients IV [i. e., clone D2 (Fig. 1)] and V [i. e., clone E2 (Fig. 1)]. This initiatory screening for possible $\mathrm{mH}$ antigenic responses favors the existence of immunodominant $\mathrm{mH}$ antigens.

Discordance of HA-2 and HA-3. A fifth $\mathrm{mH}$ antigen specificity recognized in association with HLA-A1 was identified by the CTL clones $\mathrm{C} 1, \mathrm{C} 2$, and $\mathrm{C} 3$. This specificity which was designated HA- 3 because of its concordance with the original CTL line HA-3, occurred with a phenotype frequency of $87 \%$ in the HLA-A1 positive population (data not shown). Since the specificities HA-2 and HA-3 have comparable high phenotype frequencies, but occur with different restriction molecules, we investigated the coexpression of these $\mathrm{mH}$ antigens on target cells expressing both HLA-A1 and HLA-A2. As shown in Table 3 , in seven out of 38 cases a discordance was found between the reactivity patterns of the HA-2 and HA-3-specific clones, indicating that those $\mathrm{mH}$ antigens are most likely different $\mathrm{mH}$ antigenic entities.

\section{Discussion}

Here we report on a comprehensive population genetic analysis of five HLA class I restricted $\mathrm{mH}$ antigens using $\mathrm{mH}$ antigen-specific CTL clones. These analyses shed new light on the current estimations of $\mathrm{mH}$ antigen immunogenecity and polymorphism in humans. The latter has been thought to be extensive, based on the common occurrence of rejection or graft vs host disease after HLAidentical BMT (Thomas et al. 1975; Storb et al. 1983). The data shown in this communication are not incompatible with this notion; however, they indicate a more limited $\mathrm{mH}$ antigen repertoire which may be regulated by two mechanisms. The first is thought to operate at the level of $\mathrm{mH}$ antigen genes, and the second at the level of the CTL response. In support of the first mechanism are the phenotype frequencies found for the $\mathrm{mH}$ antigens under study. Two specificities, namely HA-2 and HA-3, are almost ubiquitous, being expressed in $95 \%$ and $87 \%$ of the HLA-matched population respectively. Likewise, an HLA-B7 restricted $\mathrm{mH}$ antigen $\mathrm{W} 1$ with a phenotype frequency as high as $80 \%$ has been described by Pierson and Elkins (1987). Thus, high phenotype frequencies for $\mathrm{mH}$ antigens seem to be common, indicating that, at least for several $\mathrm{mH}$ antigen loci, the allelic variation is limited. On explanation for the high phenotype frequencies as found for HA-2 and HA-3, is that these $\mathrm{mH}$ antigens may be encoded by more than one gene. It has been reported for a murine $\mathrm{mH}$ antigen that two independently segregating genes, both of which encode self ligands, are responsible for deleting particular Ter $\mathrm{V} \beta$-expressing $\mathrm{T}$ cells (Tomanari and Fairchild 1991). Another explanation could be that the apparently frequent coexpression of HLA-restriction molecules, and some $\mathrm{mH}$ antigen specificities, is a direct result of linkage of $\mathrm{mH}$ genes to the MHC on chromosome 6. Family studies are currently being carried out to investigate this possibility.

In addition, another frequent $\mathrm{mH}$ antigen, HA-1 $(69 \%)$, was identified. It has been suggested that this antigen is a possible allele of two less frequent $\mathrm{mH}$ antigens HA-4 and HA-5. Similarly in the mouse, many non-H-2 $\mathrm{mH}$ antigen loci have one very frequent allele and a low number of other very infrequent alleles (Loveland and Simpson 1986; Rammensee and Klein 1983). Investigation of possible allelism of HA-1, -4 , and -5 failed to reach a p-value equal to or greater than 0.05 . However, the differences between observed and expected numbers are not so extreme. Therefore the numbers of tested individuals should be increased to really settle this question.

Furthermore, our results are suggestive for another regulatory level for the "functional" polymorphism of $\mathrm{mH}$ antigens. Most interestingly, CTLs recognizing one single $\mathrm{mH}$ specificity, namely HA-1, could be isolated from three patients with different genetic backgrounds but sharig the HLA-A2 molecule. This particular human $\mathrm{mH}$ 
antigen behaves as a potent or maybe even immunodominant T-cell antigen. Immunodominance is a mechanism that could limit the "functional" polymorphism of $\mathrm{mH}$ antigens, and has been described for certain $\mathrm{mH}$ antigens in the mouse (Loveland and Simpson 1986; Wettstein and Baily 1982). The evidence that HA-1 behaves as a possible immunodominant $\mathrm{mH}$ antigen, however, is only preliminary. Not until we can type for more $\mathrm{mH}$ antigens and carry out an inventory of $\mathrm{mH}$ antigen response in more individuals can we conclude that the immune response to one $\mathrm{mH}$ antigen is dominated by another. Identification of the most immunogenic $\mathrm{mH}$ antigens would benefit bone marrow grafting. Typing for $\mathrm{mH}$ antigens with extremely high or low frequencies such as HA-2, HA-3, or W1 (Pierson and Elkins 1987), or HA-4 and HA-5 has only limited clinical relevance. The $\mathrm{mH}$ antigen $\mathrm{HA}-1$ could be a candidate for typing. This antigen demonstrates an interesting population frequency. Besides, it should also be noted that the anti-HA-1 CTLs were all derived from patients with severe graft-vs-host disease. However, a note of caution should be made since recent mouse studies demonstrate that the prediction of immunodominance based on in vitro CTL studies does not always correlate with the development of GvHD (Korngold and Wettstein 1990).

Acknowledgments. We would like to thank Dr. E. Simpson and Dr. J. Kurnick for helpful discussion and Mrs. I. Curiel for editing the manuscript.

\section{References}

Demotz, S., Grey, H. M., Appella, E., and Sette, A.: Characterization of a naturally processed MHC class II restricted T cell determinant of hen egg lysozyme. Nature 342: 682-684, 1989

Falk, K., Rötzschke, O., and Rammensee, H.-G.: Cellular peptide composition governed by major histocompatibility complex class I molecules. Nature 348: 248-251, 1990

Goulmy, E.: Minor Histocompatibility antigens in man and their role in transplantation. In J. Morris and N. L. Tilney (eds.): Transplantation Reviews vol 2, pp. 29-53, Saunders, 1988

Goulmy, E.: HLA-A, -B restriction of cytotoxic T cells. In S. Ferrone and B. G. Solheim (eds.): HLA typing: methodology and clinical aspects Vol 2, pp. 105-122, CRC press, New York, 1982

Irle, C., Beatty, P. G., Mickelson, E., Thomas, E. D., and Hansen, J.A.: Anti-non-major histocompatibility complex alloreactive cytotoxic $\mathrm{T}$ cell clones occurring in vivo, following HLA-identical sibling bone marrow transplantation. Transplant Proc 17: 772-773, 1985

Korngold, R. and Wettstein, P. J.: Immunodominance in the graftvs-host disease T-cell response to minor Histocompatibility antigens. J Immunol 145: 4079-4088, 1990

Loveland, B. and Simpson, E.: The non-MHC transplantation antigens: neither weak nor minor. Immunol Today 7: 223-229, 1986

Maniatis, T., Fritsch, E. F., and Sambrook: Molecular Cloning: $A$ Laboratory Manual. Cold Spring Harbor Laboratory, Cold Spring Harbor, 1982
Mattiuz, P. L., Ilde, D., Piazza, A., Ceppellini, R., and Bodmer, W. F.: New approaches to the population, genetic and segregation analysis of the Hl-A system. In P. I. Terasaki (ed.): Histocompatibility Testing, pp. 193-205, Munksgaard, Copenhagen, 1970

Miltenburg, A. M. M., Van Laar, J.M., Daha, M.R., De Vries, R. R. P., Van den Elsen, P., and Breedveld, F. C.: Dominant T-cell receptor $\beta$ chain gene rearrangements indicate clonal expansion in the rheumatoid joint. Scand J Immunol 31: 121-125, 1990

Nicklas, J. A., Hunter, T. C., Sullivan, L. M., Berman, J. K., O'Neill, J. P., and Albertini, R. J.: Molecular analysis of in vivo hprt mutation in human T-lymphocytes I. Studies of low frequency "spontaneous" mutants by southern blots. Mutagenesis 2: 341-347, 1987

Pierson, G. R. and Elkins, W. L.: Limited polymorphism of minor histocompatibility loci in relation to bone marrow transplantation. In A. R. Liss (ed.): Progress in Bone Marrow Transplantation, pp. 307-314, 1987

Rammensee, H.-G. and Klein, J.: Polymorphism of minor Histocompatibility genes in wild mice. Immunogenetics 17: 637-647, 1983

Reinsmoen, N. L., Kersey, J. H., and Bach, F. H.: Detection of HLA restricted anti minor Histocompatibility antigen(s) reactive cells from skin GVDH lesions. Hum Immunol 11: 249-257, 1984

Rötzschke, O., Falk, K., Deres, K., Schild, H., Norda, M., Metzger, J., Jung, G., and Rammensee, H.-G.: Isolation and analysis of naturally processed viral paptides as recognized by cytotoxic $\mathrm{T}$ cells. Nature 348: 252-254, 1990a

Rötzschke, O., Falk, K., Wallny, H.-J., Faath, S., and Rammensee, H.-G.: Characterization of naturally occurring minor Histocompatibility peptides including H-4 and H-Y. Science 249: 283-287, $1990 \mathrm{~b}$

Storb, R., Prentice, R. L., Thomas, E. D., Appelbaum, F. R., Deeg, H. J., Doney, K., Fefer, A., Goodell, B.W., Mickelson, E., Stewart, P., Sullivan, K. M., and Witherspoon, R. P.: Factors associated with graft rejection after HLA-identical marrow transplantation for aplastic anemia. Br J Haematol 55: 573-585, 1983

Thomas. E. D., Storb, R., Clift, R. A., Fefer, A., Johnson, F. L., Neiman, P.E., Lerner, K. G., Glucksburg, H., and Buckner, C. D.: Bone marrow transplantation. New Engl J Med 292: 832-902, 1975

Tomonari, K. and Fairchild, S.: The genetic basis of negative selection of Tc2b-V11 ${ }^{+}$T cells. Immunogenetics 33: 157-162, 1991

Van Els, C. A. C. M., Bakker, A., Zwinderman, A. H., Zwaan, F. E., Van Rood, J. J., and Goulmy, E.: Effector cell mechanisms in Graft-vs-Host Disease in response to minor Histocompatibility antigens. I. Absence of correlation with cytotoxic effector cells. Transplantation 50: 62-66, 1990a

Van Els, C.A.C.M., Zantvoort, E., Jacobs, N., Bakker, A., Van Rood, J. J., and Goulmy, E.: Graft-versus-Host Disease associated $\mathrm{T}$ helper cell responses specific for minor Histocompatibility antigens are mainly restricted by HLA-DR. Bone Marrow Transplant 5: 365-372, 1990b

Wettstein, P. J. and Baily, D. W.: Immunodominance in the immune response to "multiple" histocompatibility antigens. Immunogenetics 16: 47-58,1982

Wettstein, P. J.: In S. D. Litwin (ed.): Human Immunogenetics, pp. 339-357, Marcel Dekker, New York, 1989

Yasuda, N. and Kimura, M.: A gene counting method of a maximum likelyhood for estimating gene frequencies in $\mathrm{ABO}$ and $\mathrm{ABO}-$ like systems. Ann Hum Genetic 31: 409, 1968

Yoshihai, Y., Antoniuo, D., Clark, S. P., Yanangi, Y., Sangster, R., Van den Elsen, P., Terhorst, C., and Mak, T.: Sequence and expression of transcripts of the human $\mathrm{T}$-cell receptor $\beta$-chain genes. Nature 312: 521-524, 1984 